\title{
(i) Strategic Analysis of Selected Factors Shaping the Occupational Health and Safety Culture of Mining Companies in Poland, Part 2

\author{
Mariusz KAPUSTA ${ }^{1)}$, Patrycja BĄK ${ }^{2)}$, Marta SUKIENNIK ${ }^{3)}$
}

${ }^{1)}$ AGH University of Science and Technology, Faculty of Mining and Geoengineering; email: kaputsm@agh.edu.pl
${ }^{2)}$ AGH University of Science and Technology, Faculty of Mining and Geoengineering; email: pbak@agh.edu.pl
${ }^{3)}$ AGH University of Science and Technology, Faculty of Mining and Geoengineering; email: marta.sukiennik@agh.edu.pl

http://doi.org/10.29227/IM-2020-01-81

Submission date: 28-12-2019| Review date: 12-02-2020

\section{Abstract}

This paper is a continuation of the paper published in issue 2 of the 2019 journal. It includes a further analysis of the impact of selected factors shaping the OHS culture in Polish mining companies. The first half of 2020 sees the world combating the coronavirus. In the case of operations carried out by mining companies, the virus threat must necessarily be considered. What is more, this threat becomes even more significant when the energy security of Poland is taken into account. The paper presents the results of the strategic analysis carried out for a selected group of factors that shape the OHS culture in companies.

Keywords: organisational culture, mining industry, SWOT analysis, OHS culture, Covid-19 in mines

\section{Introduction}

This paper is a continuation of the paper with the results of the research and analysis conducted by the authors. In the first part of the paper, the authors revealed the results of the strategic analysis of selected factors shaping the occupational health and safety culture in a company based on SWOT analysis. The analysis covered three areas, which were included in surveys. These areas were occupational risk assessment, scope of hazard identification, and training in and observance of OHS rules. The results are presented in detail in the paper [5]. This paper analyses the remaining three areas, which are included when plotting a grid of the occupational health and safety culture. These areas are company's visions and goals, control of the safety and behaviour of management personnel, and accidents and near misses.

SWOT analysis in the area of occupational health and safety is closely related to the concept of organisational culture because the very definition of significant factors determining the shape and level of the OSH culture is not always sufficient for good OSH culture management. The OSH culture is one of the components of organisational culture; therefore, the strategic analysis of factors shaping it provides firm support for managers.

The issue of organisational culture has been addressed and examined by authors in papers [1], [2], [10], [11], [12], [14], [16]. The basis for this paper (both parts) was the research whose results were published by these authors in papers [8], [13], [15].

The safety culture grid is a tool to determine how much a given factor affects the shape of the general OHS culture policy in the analysed organisation. The higher the score of a factor, the better employees and organisation members evaluate solutions used by the organisation in this respect. The following chapters describe the characteristics of SWOT analysis for selected factors included in the OHS culture grid. They include:
- company's visions and goals,

- control of the safety and behaviour of management personnel,

- $\quad$ accidents and near misses.

Figure 1 shows these factors together with the score that they obtained in surveys conducted among employees of mining companies [5] and [8].

2. Strategic Analysis in Terms of Assessing the Company's Visions and Goals

Every company - as a component of the socio-economic system - pursues its goal by meeting the needs of the society, customers, its employees, management, and owners. To maintain a long-term role in a dynamic social system, the company has to balance its interests against public interests or, at least, show respect for social values and expectations when pursuing economic goals [4]. For mining companies, these goals are closely correlated with the state economy, ensuring the energy security in the country, as well as are strongly determined by a number of factors. The European Union policy, a number of conditions related to environmental requirements, as well as economic and political decisions in the country have a considerable impact on both setting and pursuing goals.

The goals of an organisation may be classified based on different points of view. The most important ones include [9]:

- form: qualitative or quantitative (there are generally hierarchical relationships between them, goals in qualitative form are the most general),

- time frame in which goals are to be achieved (short-, medium-, and long-term goals),

- the way how goals are expressed (stated goals, i.e. ostensible and actual goals, i.e. real actions),

- freedom to shape goals (objective and subjective goals),

- goal interference (compatible and conflicting goals), 


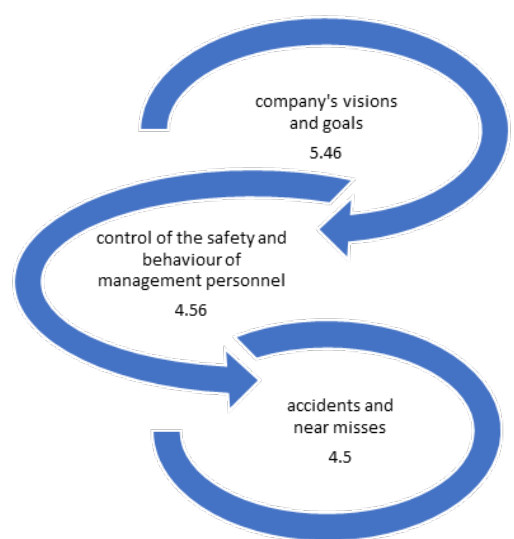

Fig. 1. Selected factors of the OHS culture grid and their results based on research results. Source: [4] Rys. 1. Wybrane czynniki siatki kultury BHP i ich wyniki na podstawie wyników badań. Źródło: [4]

- the degree of severity of goals (goals may be extreme, i.e. based on maximising or minimising, or satisfying.

In the case of mining companies, it seems that their vision is basically consistent and focuses on their core business, i.e. mining. Even though their vision depends on horizontal relationships within the groups of companies in which they operate, they reflect common trends.

Polska Grupa Górnicza SA defines its vision as "continuous development of competence in the field of deposit management and production of a high-quality product, maintaining social responsibility for the decisions taken"; in its vision, JSW SA defines itself as "a supplier of a strategic chemical raw material necessary to manufacture steel, which is the basis for sustainable development and transformation into a low-carbon economy". The vision of Lubelski Węgiel Bogdanka assumes that it is "a strong link in the Enea Group's value chain and a leader in the field of mining industry efficiency with the highest occupational safety standards". The KGHM's vision includes "the effective use of its resources to become a leader in the field of sustainable development".

When it comes to the goals of these companies, discrepancies may be observed. These goals are strongly dependent on internal conditions and divided into areas.

The issue of goals set by entities operating on the mining market in terms of organisational culture will be the topic of the next paper by the authors, in which goals in a long-term perspective will be analysed in detail.

\section{Strategic Analysis in Terms of the Control of Safety and Behaviour of Management Personnel}

Control of the safety and behaviour of management personnel is a key element in shaping occupational safety in companies. The immediate superior of an employee organises, supervises, and controls his/her work. The attitude of the superior has a considerable effect on the occupational hazards of his/her subordinate employees. The analysis of the impact of management personnel on improving OHS is a continuous subject of research aimed at identifying risks and defining recommendations to improve safety [3], [6], [7]. Information obtained through discussions and face-to-face interviews with management personnel makes it possible to formulate SWOT analysis factors. This research method enables a more accurate identification of risks, taking into account respondents' observations and comments.

Figures 2 and 3 show strengths, weaknesses, opportunities, and threats of controlling the safety and behaviour of management personnel of hard coal mines.

Strengths: In mining companies, management personnel have high qualifications, which are additionally governed by the provisions of the Geological and Mining Law. Their career paths are closely linked to the reception of appropriate higher education and the completion of professional training. Promotions are verified by an external authority - the State Mining Authority. Further promotions to senior management are hierarchically dependent on years of experience. In addition, such employees often undergo training in risks within a company and training that directly results from industry regulations. Frequent knowledge updates resulting from changing technical and organisations conditions in the working environment are also a strength. Another strength is associated with widely used procedures and supporting management systems.

Weaknesses: Currently, the main problem faced by companies is low interest in working in mines. Low levels of recruitment to mining universities cause a shortage of managerial staff. As a result, the average job seniority of persons responsible for supervision in a company increases every year. The central problem for candidates is the specificity of jobs in mines (severe environmental conditions) and disproportionate remuneration. On the other hand, experienced employees get bored by their routine and become affected by professional burnout, which leads to a drop in safety and initiates incidents. In addition, employees often report contradictions in instructions given by different mine management personnel.

Opportunities: A limited ability to supervise employees makes it necessary to control them through video surveillance. Furthermore, advances in technology make it possible to limit the number of employees in hazardous zones and to carry out works remotely and without employees. However, the shortage of skilled employees, which should be met on an ongoing basis, is a frequent issue nowadays. The country's long-term energy strategy will make it possible to stabilise employment and provide the opportunity to invest in human capital. As a result, a pro-safe impact of the management attitude can be achieved, which will favour the process of continuous improvement. 


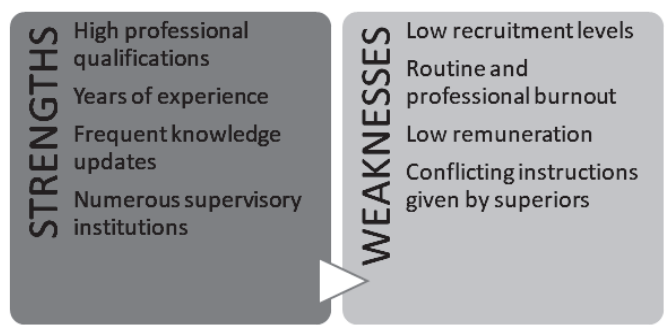

Fig. 2. Strengths and weaknesses of controlling the safety and behaviour of management personnel in a mining company. Source: authors' own elaboration Rys. 2. Mocne i słabe strony kontroli bezpieczeństwa i zachowania personelu kierowniczego w spółce górniczej. Źródło: opracowanie własne

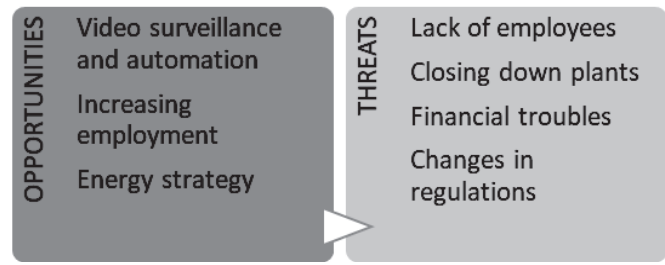

Fig. 3. Opportunities and threats of controlling the safety and behaviour of management personnel in a mining company. Source: authors' own elaboration Rys. 3. Szanse i zagrożenia związane z kontrolowaniem bezpieczeństwa i zachowania personelu kierowniczego w spółce wydobywczej. Źródło: opracowanie własne

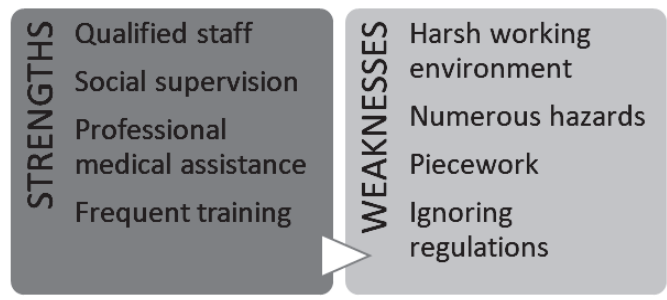

Fig. 4. Strengths and weaknesses in the area of accidents and near misses in a mining company. Source: authors' own elaboration Rys. 4. Mocne i słabe strony w obszarze wypadków i sytuacji zaginionych w firmie górniczej. Źródło: opracowanie własne

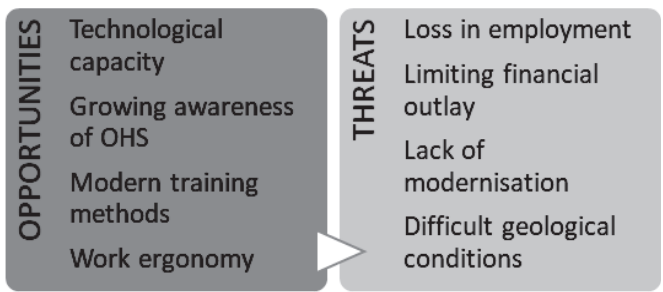

Fig. 5. Opportunities and threats in the area of accidents and near misses in a mining company. Source: authors' own elaboration Rys. 5. Szanse i zagrożenia w obszarze wypadków i potencjalnych wypadków w firmie górniczej. Źródło: opracowanie własne

Threats: The main threat in companies is a drastic decrease in employees' interest in working in managerial positions. The uncertain future of the industry, possibility of closing down mines, high qualification requirements, working in shifts, and a high risk of accidents and diseases constitute a stereotype that is deeply rooted in the society and reinforced by the media. Even numerous mining privileges (coal allowance, early retirement, etc.) are currently unable to encourage potential employees to work in managerial positions in mines. Slow changes to regulations will probably lead to a considerable decline in safety within a few years, which will directly affect the financial problems of companies.

\section{Strategic Analysis in Terms of Accidents and Near Misses}

Work-related accidents can be usually divided into non-injury and injury accidents. The so-called injury accidents include workplace accidents, accidents considered to be equal to workplace accidents, and accidents on the way to and/or from work. On the other hand, non-injury accidents include near misses. Only injury accidents are included in the safety analysis statistics of companies. Still, mining companies with a high safety culture identify and analyse near misses on an ongoing basis. Such actions make it possible to limit or often even eliminate workplace accidents. It should also be emphasised that such actions require the full involvement of both management personnel and mine employees.

The analysis of accidents and near misses is not only a tool used to collect information about the number and consequences of accidents but, most of all, a tool that can be used to take corrective and preventive actions in order to limit and eliminate causes of accidents. Accident rates, e.g. an accident frequency and severity rate, are often used to compare safety between companies. However, studies indicate that these rates often do not really reflect the existing situation. This stems 
from the fact that in units in which more employees work (coal mines) the probability of an accident is higher compared to companies with fewer employees.

Figures 4 and 5 show strengths and weaknesses as well as opportunities and threats related to actions taken in the area of accidents and near misses for underground mines.

Strengths: People working in OHS departments as well as persons responsible for management systems have high qualifications, skills, and many years of experience. They can determine the amount of the risk, including employees' habits and inappropriate behaviour. In terms of controlling working conditions, social supervision represented by trade units and social labour inspectorate plays a major role. In the event of an accident, companies have a qualified mine rescue service and immediate medical assistance at their disposal. $\mathrm{Nu}-$ merous training sessions and exchange of experiences from accident situations make it possible to gain knowledge and develop skills.

Weaknesses: The cause of accidents and near misses is mainly the specific working environment and its natural hazards. The most tragic accidents (catastrophes) are related to the following hazards: methane, fire, and coal dust explosion hazards. What is more, the economic aspect of piecework often leads to breaking regulations and bringing about hazardous situations. That is why the most frequent cause of accidents in underground mining is a human factor (human error), which is found in over $80 \%$ of cases. It should be noted that these causes are states for both employees and their superiors.

Opportunities: A considerable decrease in accidents can only be achieved by minimising the number of employees performing works. Advances in technology make it possible to perform works remotely by automating production processes. Innovative training methods provide the means for simulating accident situations using virtual learning. Employees can be prepared to display desirable behaviour and perform desirable actions through awareness building and knowledge sharing. Another important aspect is the use of ergonomic solutions, which - by reducing the biological costs of employees - improve safety and increase productivity. Ergonomic solutions should cover the following areas: technical, economic, and organisational as well as medical, including occupational psychology.
Threats: A considerable threat in the area of accidents may include further workforce reductions, which will increase the scope of activities performed by employees. Therefore, pressure and haste increase the probability of making mistakes and creating accident or near-miss situations. Financial savings can also significantly reduce people's creativity to shape occupational safety. Financial troubles may lead to a lack of equipment and device modernisation and an increase in failures and downtime, raising occupational risk. In addition, the safety of mine employees is closely related to natural hazards, which increase with the depth at which mining operations are performed. If financial outlay on investments is reduced, an increase in accidents and near misses must be expected.

\section{Conclusion}

A comprehensive analysis of factors shaping the occupational health and safety culture based on SWOT analysis makes it possible to identify both strengths that reinforce the shape and impact of the culture in a company and opportunities that management personnel should use to improve the quality of the culture in a given area. If properly identified and used, opportunities and threats allow companies to reinforce the above-mentioned culture. The issue of COVID-19 cannot be evaded in this analysis, especially because May 2020 is when mines are particularly affected by the virus. It cannot be ignored how much impact the virus had on the vision, current activities, and goals either. Even in companies where COVID-19 is not present (Lubelski Węgiel Bogdanka) it was necessary to implement new organisational, technical, and managerial solutions. Mining operations were stopped in entities where employees became infected with the virus. It is without doubt that COVID-19 will bring about changes in the organisational culture of companies - not only mining ones. The trend of remote working is already widely used and stressed by some companies as the one that is to replace traditional office work. In the case of mining entities, OHS aspects had to be reconsidered. Sociologists point to changes in relations between people. Consequently, the current shape and directions of organisational culture development in different entities will be transformed in the near future.

The paper presents results of research conducted in AGH University of Science and Technology no. 6.16.100.215 


\section{Literatura - References}

1. Bąk P, Sukiennik M., Impact of corporate culture on business goals of energy sector companies, IOP Conference Series: Earth and Environmental Science ; ISSN 1755-1307, 2019 vol. 214 [no.] 1 art. no. 012066

2. Bąk P, Sukiennik M., Kowal B., Corporate culture in terms of management processes in the Polish mining companies, Inzynieria Mineralna V. 17, I. 2, P.135-144, 2016

3. Danielak W., Kapusta M., Kraszewska M., Innowacje w zarządzaniu przedsiębiorstwem: studia przypadków, monografia, Exante Wydawnictwo Naukowe, 2018 Wrocław

4. Grzegorzewska-Ramocka E., Cele ekonomiczne i społeczne przedsiębiorstwa, Gospodarka Narodowa 233 (7-8), 2009

5. Kapusta M., Bąk P., Sukiennik M., A strategic analysis of selected factors that create the culture of occupational health and safety in mining companies in Poland, Pt. 1, Inżynieria Mineralna = Journal of the Polish Mineral Engineering Society ; ISSN 1640-4920, 2019 R. 21 nr 2, s. 287-292

6. Kapusta M., Impact of mining executives on improving occupational safety and health, Inżynieria Mineralna - Journal of the Polish Mineral Engineering Society, ISSN 1640-9420 - 2017 R. Nr 2(40) s.183-194

7. Kapusta M., Research on learning safety and hygiene in a mining company, Zeszyty Naukowe Politechniki Rzeszowskiej. Ekonomia i Nauki Humanistyczne. ISSN: 1234-3684, - 2018 vol. 23 no. 25, s.111-124

8. Kapusta M., Sukiennik M., Bąk P., Effectiveness of occupational health and safety rules in shaping organizational culture, Inżynieria Mineralna = Journal of the Polish Mineral Engineering Society ; ISSN 1640-4920. — 2018 R. 19 nr 1, s. 245-254

9. Pierścionek Z., Strategie rozwoju firmy, Wydawnictwo Naukowe PWN, Warszawa, 1996

10. Sukiennik M., Bąk P, Applying lean management solutions in the context of the organisational culture of energy sector enterprises, Inżynieria Mineralna = Journal of the Polish Mineral Engineering Society ; ISSN 1640-4920., 2018 R. 20 nr 2, s. 117-122.

11. Sukiennik M., Bąk P , Corporate culture versus CSR in Polish companies of the energy sector, IOP Conference Series: Earth and Environmental Science ; ISSN 1755-1307. — 2019 vol. 214 [no.] 1 art. no. 012075

12. Sukiennik M., Bąk P., The formation of organizational culture in the aspect of lean management principles in the energy industry., in Energy and fuels 2018 : Kraków, 19-21 September 2018 : book of abstracts ,AGH University of Science and Technology

13. Sukiennik M., Bąk P., Kapusta M., Corporate Culture and the Human Factor in the Polish Mining Companies, Inżynieria Mineralna - Journal of the Polish Mineral Engineering Society, No 2(38), p. 125-134, 2016

14. Sukiennik, M., Bak, P., Kapusta, M., The impact of the management system on developing occupational safety awareness among employees , Inżynieria Mineralna = Journal of the Polish Mineral Engineering Society ; ISSN 1640-4920. R. 21 nr 1, s. 245-250, 2019

15. Sukiennik, M., Bak, P., Kapusta, M.: Rola kultury bezpieczeństwa i higieny pracy w przedsiębiorstwie wydobywczym, Przegląd Górniczy t. 72 nr 8, s. 11-15, 2016

16. Sukiennik, M., Bak, P., Kapusta, M.:, The contemporary employee in the creation of organisational culture in the Polish mining industry, Inżynieria Mineralna = Journal of the Polish Mineral Engineering Society ; ISSN 16404920. R. $21 \mathrm{nr} 1$, s. $225-230,2019$

\section{Analiza strategiczna wybranych czynników kształtujacych kulturę bezpieczeństwa i higieny pra- cy przedsiębiorstw branży wydobywczej $w$ Polsce, cześć 2 \\ Niniejszy artykut jest kontynuacja pracy opublikowanej w numerze 2 czasopisma z roku 2019. Zawiera dalsza część prac prowa- dzonych nad analiza wplywu wybranych czynników ksztaltujących kulturę bhp w polskich przedsiębiorstwach branży wydobywczej. Pierwsza połowa 2020 roku to walka catego świata $z$ koronawirusem. W przypadku prac realizowanych w przedsiębiorstwach wydobywczych zagrożenie wirusem siła rzeczy musi być uwzględnione, a co więcej zyskuje ono na sile w aspekcie bezpieczeństwa energetycznego Polski. W artykule zaprezentowano wyniki przeprowadzonej analizy strategicznej, przeprowadzonej dla wybranej grupy czynników kształtujących kulturę bhp w przedsiębiorstwach.}

Słowa kluczowe: kultura organizacyjna, przemysł wydobywczy, analiza SWOT, kultura BHP, Covid-19 w kopalniach 
